\title{
Impact of Coronavirus Disease 2019 in a French Cohort of Myasthenia Gravis
}

Guilhem Solé, MD, Stéphane Mathis, MD, PhD, Diane Friedman, MD, Emmanuelle Salort-Campana, MD, Céline Tard, MD, Françoise Bouhour, MD, Armelle Magot, MD, Djillali Annane, MD, PhD, Bernard Clair, MD, Gwendal Le Masson, MD, PhD, Antoine Soulages, MD, Fanny Duval, MD, Louis Carla, MD, Marie-Hélène Violleau, MSc, Tiphaine Saulnier, MSc, Sandrine Segovia-Kueny, MD, Léa Kern, MD, Jean-Christophe Antoine, MD, Guillemette Beaudonnet, MD, Frédérique Audic, MD, Laurent Kremer, MD, PhD, Jean-Baptiste Chanson, MD, PhD, Aleksandra Nadaj-Pakleza, MD, PhD, Tanya Stojkovic, MD,

Pascal Cintas, MD, Marco Spinazzi, MD, PhD, Alexandra Foubert-Samier, MD, PhD, and

Shahram Attarian, MD, PhD

Neurology ${ }^{\circledR}$ 2021;96:e2109-e2120. doi:10.1212/WNL.0000000000011669

\section{Abstract}

\section{Objective}

To describe the clinical characteristics and outcomes of coronavirus disease 2019 (COVID-19) among patients with myasthenia gravis (MG) and identify factors associated with COVID-19 severity in patients with MG.

\section{Methods}

The CO-MY-COVID registry was a multicenter, retrospective, observational cohort study conducted in neuromuscular referral centers and general hospitals of the FILNEMUS (Filière Neuromusculaire) network (between March 1, 2020, and June 8, 2020), including patients with MG with a confirmed or highly suspected diagnosis of COVID-19. COVID-19 was diagnosed based on a PCR test from a nasopharyngeal swab or severe acute respiratory syndrome coronavirus 2 (SARS-CoV-2) serology, thoracic CT scan, or typical symptoms. The main outcome was COVID-19 severity based on location of treatment/management (home, hospitalized in a medical unit, or in an intensive care unit). We collected information on demographic variables, general history, and risk factors for severe COVID-19. Multivariate ordinal regression models were used to identify factors associated with severe COVID-19 outcomes.

\section{Results}

Among 3,558 patients with MG registered in the French database for rare disorders, 34 (0.96\%) had COVID-19. The mean age at COVID-19 onset was 55.0 \pm 19.9 years (mean MG duration: $8.5 \pm 8.5$ years $)$. By the end of the study period, 28 patients recovered from COVID-19, 1 remained affected, and 5 died. Only high Myasthenia Gravis Foundation of America (MGFA) class $(\geq \mathrm{IV})$ before COVID-19 was associated with severe COVID-19 $(p=0.004)$; factors that were not associated included sex, MG duration, and medium MGFA classes $(\leq \mathrm{IIIb})$. The type of MG treatment had no independent effect on COVID-19 severity.

\section{Conclusions}

This registry-based cohort study shows that COVID-19 had a limited effect on most patients, and immunosuppressive medications and corticosteroids used for MG management are not risk

\author{
Correspondence \\ Dr. Solé \\ guilhem.sole@ \\ chu-bordeaux.fr
}

\section{MORE ONLINE}

COVID-19 Resources

For the latest articles, invited commentaries, and blogs from physicians around the world NPub.org/COVID19 


\section{Glossary}

Anti-AChR = anti-acetylcholine receptor antibodies; anti-MuSK = anti-muscle-specific kinase antibodies; ARDS = acute respiratory distress syndrome; COVID-19 = coronavirus disease 2019; FILNEMUS = Filière Neuromusculaire; IBD = inflammatory bowel disease; ICU = intensive care unit; IVIg = IV immunoglobulin; MG = myasthenia gravis; MGFA = Myasthenia Gravis Foundation of America; MU = medical unit; NMD = neuromuscular disorder; SARS-CoV-2 = severe acute respiratory syndrome coronavirus 2 .

factors for poorer outcomes. However, the risk of severe COVID-19 is elevated in patients with high MGFA classes (odds ratio, $102.6[4.4-2,371.9])$. These results are important for establishing evidence-based guidelines for the management of patients with MG during the COVID-19 pandemic.

Coronavirus disease 2019 (COVID-19) is caused by the severe acute respiratory syndrome coronavirus 2 (SARS-CoV-2) and was first reported in China at the end of 2019. ${ }^{1}$ COVID-19 is a worldwide pandemic that continues to spread, with $38,998,580$ known cases and 1,099,409 deaths as of October 16, 2020 (coronavirus.jhu.edu/map.html). ${ }^{2}$ COVID-19 is a predominantly respiratory tract disease that can cause acute respiratory distress syndrome (ARDS) in some patients, and severe disease appears to be linked to risk factors such as advanced age and obesity. ${ }^{3,4}$

Among neuromuscular disorders (NMDs), myasthenia gravis (MG) would be particularly at risk of being negatively affected by COVID-19 not only due to the use of immunosuppressive therapies for MG management but also because it can lead to a MG crisis. Some general recommendations have been established for the management of NMD during the COVID-19 pandemic, ${ }^{5,6}$ and specific recommendations for MG are available. ${ }^{7}$ Nonetheless, evidence for the continuation of corticosteroids and immunosuppressive medications is lacking, ${ }^{7}$ as only a few case reports of patients managed in hospitals are available $^{8-11}$ and available data from the international CAREMG registry are limited. ${ }^{12}$

This study from the French neuromuscular rare disease network (FILNEMUS [Filière Neuromusculaire]) investigated the clinical course and prognosis of patients with MG with COVID-19 to help improve MG management while the COVID-19 pandemic remains active.

\section{Methods}

\section{Data Collection}

The CO-MY-COVID registry is an observational, retrospective, national, multicenter study in 12 French sites. Registry listing was accomplished by a call for participation addressed to all sites of the French network of neuromuscular rare diseases (FILNEMUS). During the first phase of the COVID-19 epidemic, FILNEMUS network centers created patient contact cells for identifying patients with MG possibly infected by SARS-CoV-2. Patient associations (AFM-Téléthon [Association Française contre les Myopathies-Téléthon] and AMIS [Association des Myasthéniques Isolés et Solidaires]) informed their members of the existence of the registry so that patients could report to their usual monitoring center.

Patients' neurologists and medical unit (MU) and intensive care unit (ICU) physicians recorded information on (1) medical history and risk factors (see below) for severe forms of COVID-19; (2) type and history of management of MG up to the onset of COVID-19 infection; (3) diagnosis and management of COVID-19; and (4) evolution and management of MG during and after COVID-19. Risk factors for severe forms of COVID-19 were age $>65$ years, obesity (body mass index >30), chronic obstructive pulmonary disease, obstructive sleep apnea syndrome, noninvasive ventilation, arterial hypertension, and diabetes.

\section{Standard Protocol Approvals, Registrations, and Patient Consents}

Patients were recruited and informed by physicians of the FILNEMUS network and provided consent (nonopposition) for the use of medical data, which was based on French law, good clinical practice, and the General Data Protection Regulation. Pseudonymized data were located on a secure server authorized to store health data. The CO-MY-COVID registry was approved by the Île-de-France-1 Personal Protection Committee on May 20, 2020 (national number: 2020A01218-31). Recruitment is still open, but for these analyses, data from patients registered until June 8, 2020, were used. This study followed Strengthening Reporting of Observational Studies in Epidemiology (STROBE) guidelines.

\section{Population of Interest}

The diagnosis of MG was established based on the presence of suggestive symptoms and at least one of the following criteria: (1) presence of anti-acetylcholine receptor (anti-AChR) or anti-muscle-specific kinase (anti-MuSK) antibodies, (2) more than $10 \%$ decrement at repetitive nerve stimulation, (3) consistent improvement with anticholinesterase medications. Patients with congenital myasthenia or Lambert-Eaton syndrome were not included in this study. A COVID-19 diagnosis was considered definite if confirmed by a positive 
PCR test for SARS-CoV-2 on a nasopharyngeal swab or SARS-CoV-2 serology; it was considered probable if the patient presented with symptoms of a viral syndrome and at least one of the following criteria: (1) contact with a patient considered to have a definite diagnosis of COVID-19, (2) specific signs (anosmia, ageusia, or skin signs), ${ }^{13}$ (3) suggestive abnormalities on thoracic CT scan. ${ }^{14}$ Patients with possible COVID-19 infection, defined as symptoms of a viral syndrome after March 17, 2020 (date of the French lockdown), were not included.

\section{Definition of Study End Points}

The main end point was the severity of COVID-19 infection, which was defined based on management modality, namely, home-managed COVID-19 if not hospitalized, intermediate COVID-19 if hospitalized in a MU, and severe COVID-19 if the patient required ICU care. Deceased patients were categorized as severe COVID-19 irrespective of where they were managed.

\section{Statistical Analysis}

Baseline characteristics of the participants are described based on the severity of COVID-19 (represented by the nadir of care). For analyses, patients were grouped into 4 categories based on MG medications as on neither corticosteroids nor immunosuppressants, corticosteroids alone, immunosuppressants alone, or both corticosteroids and immunosuppressants. The severity of MG was assessed using the Myasthenia Gravis Foundation of America (MGFA) classification, ${ }^{15}$ and this scoring system was categorized into 3 groups for ease of statistical analysis as low-MGFA group (MGFA class I), mediumMGFA (classes II, IIa, IIb, III, IIIa, or IIIb), and high-MGFA (classes IV, IVa, IVb, or V). MG exacerbation was defined as increased MGFA class during COVID-19 and MG crisis as moving to MGFA class $\mathrm{V}$ or rapid worsening and severe muscular weakness. ${ }^{16}$ The final impact of COVID-19 on MG was assessed by categorizing changes at the last evaluation in MGFA class as stable MG/improvement (when MGFA class decreased or remained stable), or MG worsening/death (when MGFA class increased or death occurred). Patients were grouped into 2 categories based on COVID-19 onset date as on early COVID-19 onset for patients with first signs before March 24 (date of the French national lockdown and 6 incubation days) and late COVID-19 onset (after March 24). To evaluate variables that could affect the severity of COVID-19, we performed univariate ordinal regression analyses with severity of COVID-19 (home-managed, intermediate COVID19, or severe COVID-19) as the dependent variable and the following factors as independent variables: risk factors for COVID-19 (including age if $>65$ years), sex, disease duration of MG, MG medication groups (4 groups and no medication as reference), and the 3 MGFA categories (with class I as reference). Independent variables associated with severity of COVID-19 and having a $p$ value $<0.2$ in the univariate model were used in the multivariate ordinal model, wherein a $p$ value of $<0.05$ was considered statistically significant and the fit of the models was verified.

\section{Data Availability}

The authors confirm that the deidentified data supporting the findings of this study are available from the corresponding authors on reasonable request.

\section{Results}

\section{Study Population}

As of June 8, 2020, 3,558 patients (56\% female) with definite or probable diagnosis of MG were recorded in the French National Database for Rare Disorders (BNDMR). The mean age of patients recorded in the BNDMR was $61.5 \pm 20.4$ years (66.4 \pm 18.4 for men). Forty patients were listed in the COMY-COVID registry. We excluded 6 patients due to criteria such as congenital myasthenia $(\mathrm{n}=2)$ and possible COVID$19(\mathrm{n}=4)$ (figure 1$)$, and therefore included 34 patients (0.96\%) in this study: of these, 20 had definite and 14 had probable COVID-19.

\section{MG Baseline Characteristics}

The 34 patients comprised 19 female (55.9\%) and 15 male (44.1\%) patients; the mean age at MG onset was $46.4 \pm 20.9$ years (range 14-86) (table 1). The mean duration of $M G$ was $8.47 \pm 8.5$ years (range $0-33$ ), with the disease lasting $>2$ years in 25 patients $(73.5 \%)$. A classical distribution of age at MG onset was observed for women but not for men, without a preponderance for men older than 50 years (figure 2). The mean age at COVID-19 onset was $55.0 \pm$ 19.9 years, $57.7 \pm 23.6$ for men, $46.0 \pm 10$ for early COVID19 onset, and $63.1 \pm 23.1$ for late COVID-19 onset ( $p=$ $0.02)$. Eleven patients $(32.4 \%)$ were older than 65 years, but

\section{Figure 1 Study Flowchart}

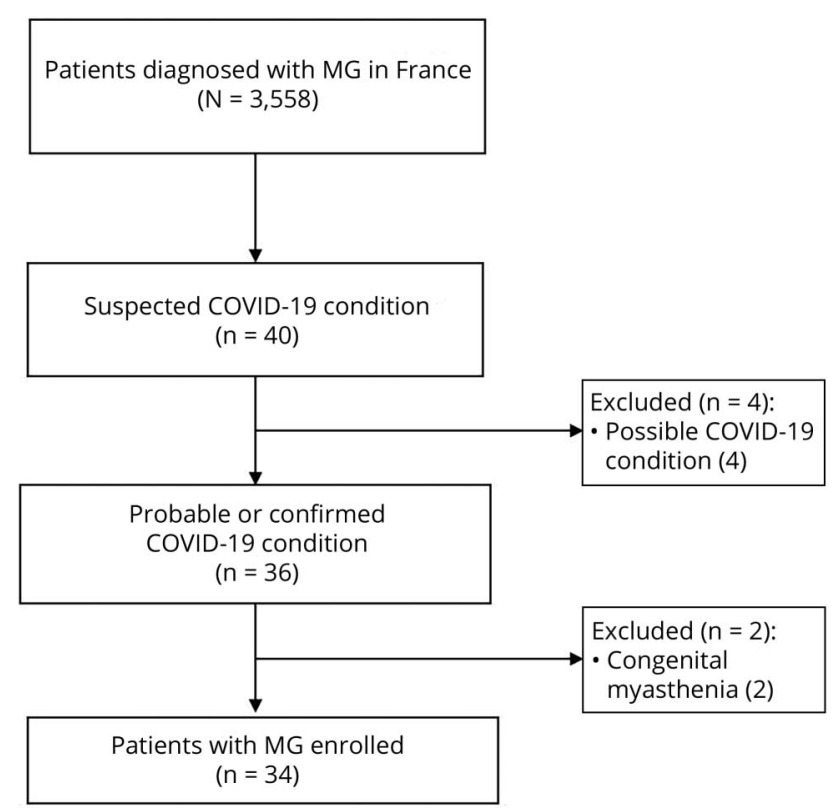

COVID-19 = coronavirus disease 2019; MG = myasthenia gravis. 
Table 1 Demographic and Disease Characteristics of Patients With Myasthenia Gravis (MG) Diagnosed With Coronavirus Disease 2019 (COVID-19) in the CO-MY-COVID Registry, as of June 8, $2020(n=34)$

\begin{tabular}{|c|c|c|c|}
\hline $\begin{array}{l}\text { Demographic and disease characteristics } \\
\text { of MG }(n=34)\end{array}$ & $\begin{array}{l}\mathrm{N}(\%) \text { or } \\
\text { mean } \pm \text { SD }\end{array}$ & $\begin{array}{l}\text { Disease characteristics and outcomes } \\
\text { of COVID-19 }(n=34)\end{array}$ & N (\%) \\
\hline Demographics & & Inclusion criteria & \\
\hline Number of patients with MG and COVID-19 & 34 & Definite COVID-19 & $20(58.8)$ \\
\hline Male/female & $19 / 15$ & Probable COVID-19 & $14(41.2)$ \\
\hline Age at COVID-19, y & $55 \pm 19.9$ & Risk factors of severe COVID-19 & \\
\hline MG history & & Male & $15(44.1)$ \\
\hline Antibody type & & Age $>65 y$ & $11(32.4)$ \\
\hline Anti-AChR & $25(73.5)$ & BMI >30 & $8(23.5)$ \\
\hline Anti-MuSK & $1(2.9)$ & COPD & $1(2.9)$ \\
\hline Neither anti-AChR nor anti-MuSK & $8(23.5)$ & OSAS & $4(11.8)$ \\
\hline Age at MG diagnosis, y & $46.4 \pm 20.9$ & Ventilation & $1(2.9)$ \\
\hline Maximum MGFA class & & HBP & $7(20.6)$ \\
\hline Low MGFA ${ }^{a}$ & $2(5.9)$ & DM & $5(14.7)$ \\
\hline Medium MGFA & $12(35.3)$ & Other & $5(14.7)$ \\
\hline High MGFA ${ }^{c}$ & $20(58.8)$ & COVID-19 onset & \\
\hline MG duration, y & $8.5 \pm 8.5$ & Early onset (before March 24, 2020) & $16(47.1)$ \\
\hline Thymectomy & $6(17.6)$ & Late onset (after March 24, 2020) & $18(52.9)$ \\
\hline MG assessment at the beginning of COVID-19 & & Age at COVID-19, y & \\
\hline MGFA class & & Early onset (before March 24, 2020) & $46.0 \pm 10$ \\
\hline Low MGFA ${ }^{a}$ & $9(26.5)$ & Late onset (after March 24, 2020) & $63.1 \pm 23.1$ \\
\hline Medium MGFA & $19(55.9)$ & COVID-19 total duration, $d$ & $28.9(20.9)$ \\
\hline High MGFAc & $6(17.6)$ & COVID-19 severity & \\
\hline MG-ADL score ${ }^{d}$ & $5.18 \pm 3.77$ & Home-managed & $15(44.1)$ \\
\hline Treatment & & Intermediate & $10(29.4)$ \\
\hline Anticholinesterase & $33(97.1)$ & Severe & $9(26.5)$ \\
\hline Neither corticosteroids or immunosuppressants & $8(23.5)$ & Affected organs & \\
\hline Corticosteroids (without immunosuppressants) & $4(11.8)$ & Upper airways & $24(70.6)$ \\
\hline Immunosuppressants (without corticosteroids) & $11(32.4)$ & Lower airways & $29(85.3)$ \\
\hline AZA & $6(17.7)$ & Smell/taste loss & $10(29.4)$ \\
\hline MFM & $3(8.8)$ & CNS involvement & $4(11 / 7)$ \\
\hline Rituximab & $2(5.9)$ & PNS involvement & $0(0)$ \\
\hline Immunosuppressants + corticosteroids & $11(32.4)$ & Gastrointestinal tract & $16(47.1)$ \\
\hline AZA & $4(11.8)$ & Heart & $2(5.9)$ \\
\hline MFM $^{e}$ & $3(8.8)$ & Thromboembolic disease & $0(0)$ \\
\hline Rituximab $^{\mathrm{e}}$ & $4(11.8)$ & Skin & $5(14.7)$ \\
\hline Tacrolimus & $1(2.9)$ & Management localization & \\
\hline PLEX (in the last 6 months) & - & Home & $15(44.1)$ \\
\hline SClg or IVIg (in the last 6 months) & $3(8.8)$ & Medical unit & $11(32.4)$ \\
\hline
\end{tabular}


Table 1 Demographic and Disease Characteristics of Patients With Myasthenia Gravis (MG) Diagnosed With Coronavirus Disease 2019 (COVID-19) in the CO-MY-COVID Registry, as of June 8, 2020 ( $n=34)$ (continued)

\begin{tabular}{|c|c|c|c|}
\hline $\begin{array}{l}\text { Demographic and disease characteristics } \\
\text { of MG }(n=34)\end{array}$ & $\begin{array}{l}N(\%) \text { or } \\
\text { mean } \pm S D\end{array}$ & $\begin{array}{l}\text { Disease characteristics and outcomes } \\
\text { of COVID-19 }(n=34)\end{array}$ & N (\%) \\
\hline MG outcome at last evaluation & & ICU & $8(23.5)$ \\
\hline Death & $5(14.7)$ & Total duration of hospitalization, $\mathrm{d}^{\mathrm{h}}$ & $11.2 \pm 9.6$ \\
\hline MGFA class evolution ${ }^{f}$ & & Duration of hospitalization in ICU, $d^{i}$ & $16.9 \pm 15.6$ \\
\hline Return to the previous state or improvement & $25(86.2)$ & Duration of total follow-up, $d$ & $38.9 \pm 18.5$ \\
\hline Worsening & $15(13.8)$ & Treatment changes due to COVID-19 & \\
\hline \multirow[t]{11}{*}{ MG-ADL score ${ }^{g}$} & $4.57 \pm 3.86$ & Increase of corticosteroids & $2(5.9)$ \\
\hline & & Modification of immunosuppressants & $5(14.7)$ \\
\hline & & HCQ & $3(8.8)$ \\
\hline & & Azithromycin & $4(11.8)$ \\
\hline & & Tocilizumab & $1(2.9)$ \\
\hline & & Antiretroviral therapy & $3(8.8)$ \\
\hline & & IVIg & $1(2.9)$ \\
\hline & & COVID-19 outcome at last evaluation & \\
\hline & & Cured & $28(82.4)$ \\
\hline & & Ongoing & $1(2.9)$ \\
\hline & & Death & $5(14.7)$ \\
\hline \multicolumn{4}{|c|}{ 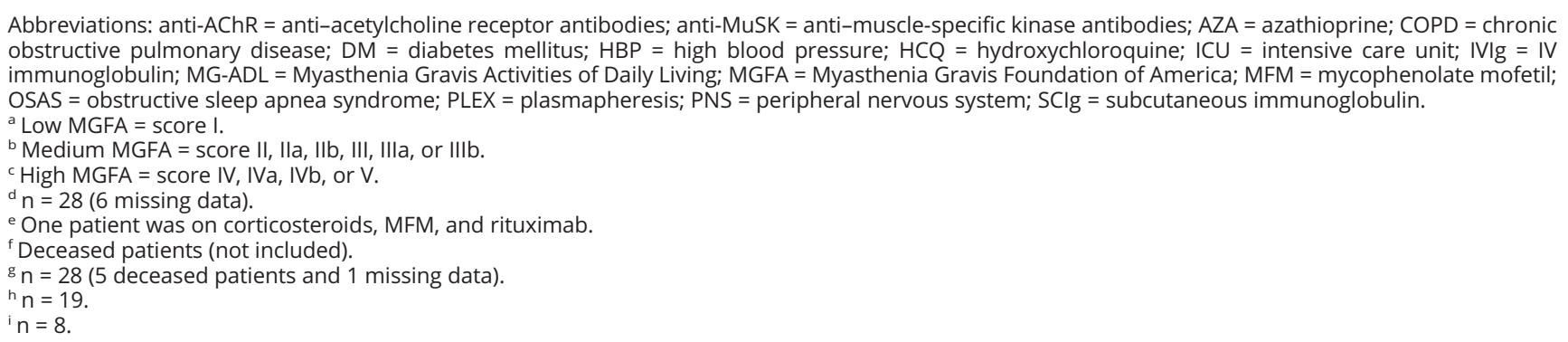 } \\
\hline
\end{tabular}

none were in the high-MGFA group. Further, 25 patients (73.5\%) had anti-AChR antibodies, 1 (2.9\%) had antiMuSK antibodies, and 8 (23.5\%) had neither anti-AChR nor anti-MuSK antibodies. Next, 9 patients (26.5\%) were categorized as low MGFA, 19 (55.9\%) as medium MGFA, and $6(17.6 \%)$ as high MGFA. All patients but one used anticholinesterase, $8(23.5 \%)$ had no other MG therapy; some were treated by corticosteroids alone $(n=4 ; 11.8 \%)$, immunosuppressants alone $(\mathrm{n}=11 ; 32.4 \%)$, or both $(\mathrm{n}=$ $11 ; 32.4 \%$ ) (figure $3 \mathrm{~A}$ ). Among patients treated with immunosuppressants, rituximab was prescribed to 6 patients in the following manner: rituximab-corticosteroids combination for 3 , corticosteroids with mycophenolate mofetil for 1 , and rituximab alone for 2 patients. Further, 2 anti-AChRpositive patients had received IV immunoglobulin (IVIg) in the last 6 months before COVID-19, whereas one patient (without antibody positivity) was treated with SC immunoglobulin.

\section{COVID-19 Characteristics and Outcome}

At the COVID-19 nadir, 15 patients (44.1\%) were homemanaged, 10 patients (29.4\%) had intermediate COVID19, and 9 (26.5\%) had severe COVID-19 (table 1). The mean number of risk factors for severe COVID-19 was $1.3 \pm$ 1.6 (range 0-6). Eleven patients (32.4\%) were older than 65 ; of these, 3 were home-managed, 6 had intermediate COVID-19, and 2 had severe COVID-19. Obesity was observed in 8 patients $(23.5 \%)$; of these, 4 were homemanaged, 3 had intermediate COVID-19, and 1 had severe COVID-19.

Five patients (14.7\%) died due to COVID-19; of these, 2 (40\%) died from ARDS only, 2 (40\%) from concomitant ARDS and multiorgan failure, and 1 (20\%) from concomitant ARDS and bacterial infections (table 2). Four patients were managed in the ICU, 1 in the MU; none of them were diagnosed as MG crisis. Among the 29 
Figure 2 Age and Sex Distribution at the Onset of Myasthenia Gravis (MG)

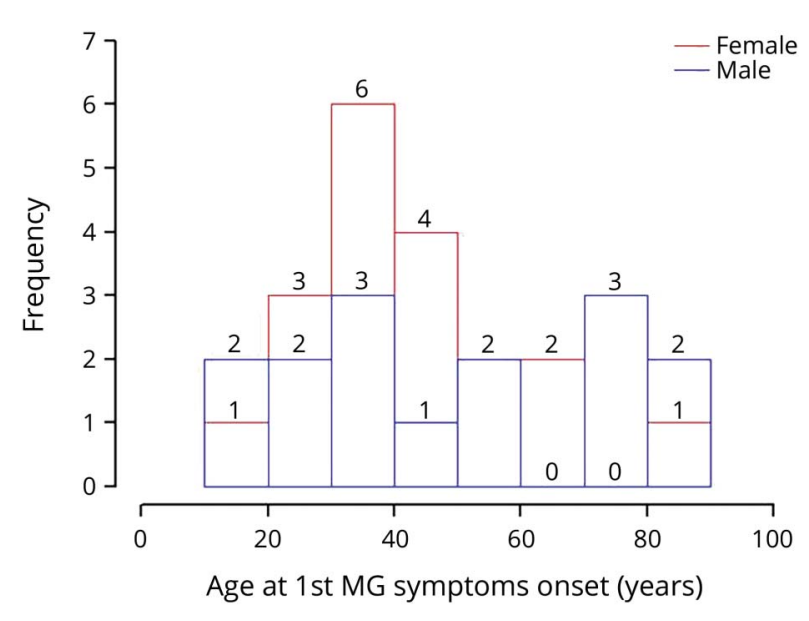

survivors, $10(34.5 \%)$ were considered to have MG exacerbation ( 1 case of MG crisis was due to a rapid MG weakness worsening treated by IVIg). MG medications were modified for 6: pyridostigmine was increased for 1 , corticosteroids were temporarily increased for 1 , and immunosuppressants were temporarily modified or stopped for 4 . Five patients with a poor prognosis were treated by hydroxychloroquine and/or azithromycin: 2 died, MGFA class was stable for 1, MGFA worsened for 1, and MGFA improved for 1. MGFA class at the last evaluation was either stable or improved in 25 patients $(86.2 \%)$, but worsened in 4 patients $(13.8 \%)$.

\section{Risk Factors Associated With COVID-19 Severity and MG Worsening}

In univariate analysis, high MGFA class was strongly associated with severe COVID-19 $(p=0.0008)$ (table 3 and figure 3B), while medium MGFA class only tended to be associated with severe COVID-19 $(p=0.064)$. Treatment of MG with corticosteroids alone showed nonsignificant trend for association with severe COVID-19 $(p=0.067)$, while immunosuppressants alone or immunosuppressants + corticosteroids showed significant association with severe COVID-19 (respectively $p=0.038$ and $p=0.035$ ) (figure $3 \mathrm{~A})$. No dose effect was identified; no other independent variable tested was associated with a severe form of COVID19. Treatment group and MGFA categories were introduced in the multivariate model based on variables determined to be significant in the univariate ordinal models. Within a given category of MGFA class, the type of treatment had no effect on the severity of COVID-19, and only high MGFA before COVID-19 was independently associated $(p=0.004)$ with a more severe course of COVID-19 (table 3 and figure $3 \mathrm{C})$. In univariate analysis, no group was associated with poorer outcomes for MG (table 4).

\section{Discussion}

MG is an immune-mediated NMD that results in muscle weakness (including bulbar and respiratory muscles) often requiring corticosteroids or immunosuppressants therapy. Infections (usually pneumonia or upper respiratory infection) are a common precipitating factor for myasthenic crisis ${ }^{17}$ and are a source of therapeutic dilemma in the management of MG. ${ }^{18,19}$ International experts and French experts from the FILNEMUS network were quick to propose guidelines for COVID-19 management in patients with $\mathrm{MG} .^{6,7}$ As France was one of the earliest countries to endure a widespread COVID-19 outbreak, our experience with real-life cases may facilitate the development of evidence-based guidance.

The known risk factors for the severe form of COVID-19 are older age, cardiovascular disease, diabetes, chronic respiratory disease, hypertension, obesity, and cancer. ${ }^{20}$ Interestingly, in our cohort, univariate analysis only identified immunosuppressants use and severe form of MG at COVID-19 onset as risk factors rather than variables such as age. Multivariate analysis showed only MG severity as an independent risk factor for severe COVID-19 with a very high odds ratio: the impact of MG severity is so high that it probably cancels the effect of classic risk factors of severe COVID-19 such as age. Another explanation for the absence of age effect could be the lack of older patients in our series: the mean age at COVID-19 onset (55.3 years) observed was younger than that in our national database (61.5 years) and the analysis of age distribution at MG onset did not show a classical peak after 60 years, especially for men (figure 2). ${ }^{21}$ To explain why older patients with $\mathrm{MG}$ were less likely to get infected by SARS-CoV-2, we looked at the age of patients infected until March 24 (date of the national French lockdown +6 incubation days) and after: patients infected in the early phase were younger ( 46.0 years) than those infected in the late phase (63.1 years, $p=0.02$ ). The younger the people, the more social interaction and the more at risk to get infected. The same phenomenon is now observed in the second wave in France. ${ }^{22}$ This and information campaigns led by FILNEMUS and patient associations could explain why no high MGFA patient was older than 65 years.

As severe $M G$ is predominantly treated by corticosteroids or immunosuppressants (figure 2C), management of immunosuppressed patients with MG with COVID-19 is challenging. Since the announcement of the first results of the RECOVERY trial, ${ }^{23}$ corticosteroids (dexamethasone) are widely used for severe COVID-19. The benefit of dexamethasone use in severe COVID-19 was confirmed in a recent meta-analysis, ${ }^{24}$ but this effect had not been shown for hydrocortisone ${ }^{25}$ or methylprednisolone. ${ }^{24}$ By contrast, in our series, corticosteroids were not significantly associated with poor COVID-19 outcome but had no protective effect (whatever the dose was). Corticosteroids were also identified as a risk factor for severe COVID-19 in 2 large series of 600 patients with rheumatic disease ${ }^{26}$ and 523 patients with inflammatory bowel disease (IBD) ${ }^{27}$ These different results are not contradictory: in RECOVERY, 
Figure 3 Categorization of Patients With Myasthenia Gravis Diagnosed With Coronavirus Disease 2019 (COVID-19) in the CO-MY-COVID Registry, as of June 8, 2020

A

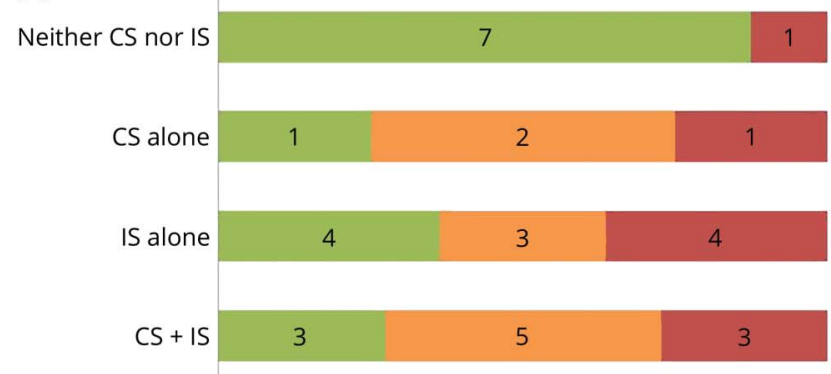

B

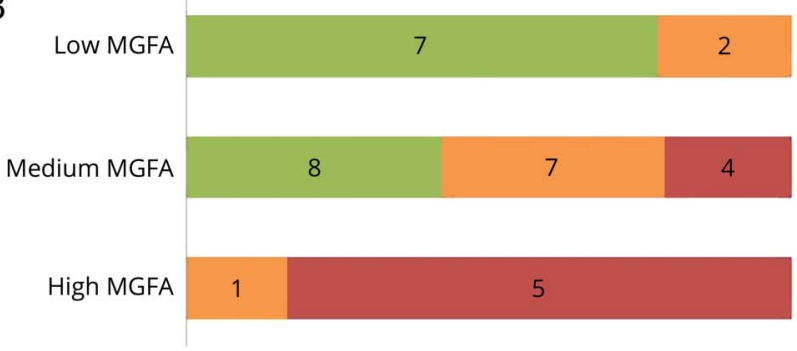

C

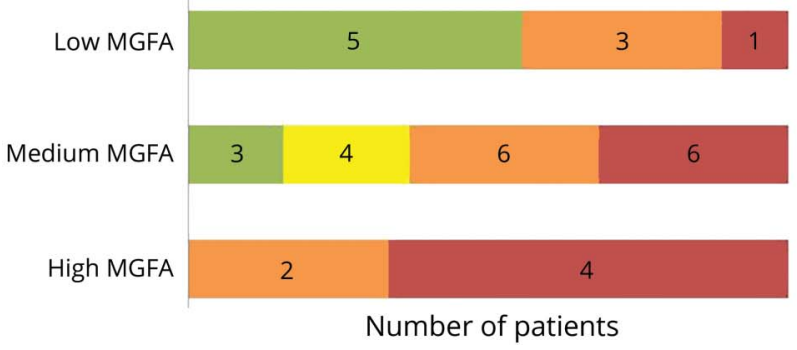

- Home-managed

- Intermediate COVID-19

- Severe COVID-19
- Home-managed

- Intermediate COVID-19

severe COVID-19
Neither CS nor IS

CS alone

IS alone

CS + IS dexamethasone was efficient in the treatment of severe COVID19 and ARDS but did not have a preventive effect on the patients who did not need ventilatory support. In this population, the fatality rate was $17.8 \%$ in the dexamethasone arm and $14 \%$ in the placebo arm $(p=0.14)$. Most other studies about dexamethasone have focused only on ICU patients and not patients with slight to moderate symptoms (as in our case). We showed that immunosuppressants are associated with a poor COVID-19 outcome in univariate analysis and not in multivariate analysis. The same absence of effect of immunosuppressants on COVID-19 outcome was also observed in large series of multiple sclerosis ${ }^{28}$ and rheumatic disease, ${ }^{26}$ including drugs targeting CD19 B cells, azathioprine, cyclophosphamide, cyclosporine, mycophenolate mofetil/mycophenolic acid, and tacrolimus. These results confirm expert-based guidelines that recommend immunosuppressants continuation. ${ }^{5,6,26}$

Distinguishing the respiratory effects of COVID-19 from MG crisis remains challenging, despite the use of chest CT scan, arterial blood gas, or spirometry. ${ }^{29,30}$ In our series, MG crisis was considered for 1 patient who experienced a rapid worsening and received IVIg; MG exacerbation was identified in 10 other patients and MG medications were increased for 2 . This rate of MG exacerbation and crisis (33.3\%) is consistent with that observed after COVID-19 in the CARE-MG registry, ${ }^{12} 2$ small series, ${ }^{8,11}$ and after influenza-like illness (40\%). ${ }^{31}$ These series and the few reports of clinical cases were predominantly focused on hospitalized patients ${ }^{8-10}$ and did not provide information on home-managed patients, whereas most patients with COVID-19 present with mild to moderate symptoms. ${ }^{2}$ The fatality rate in our study $(14.7 \%)$ was lower than that observed in the preliminary results of the CARE-MG registry $(24 \%)^{12}$ but higher than in studies of other immune-mediated diseases such as IBD $(3 \%),{ }^{27}$ rheumatic disease $(6 \%-9 \%),{ }^{26,32}$ or multiple sclerosis (3.46\%). ${ }^{28}$ One could hypothesize that either MG or COVID-19 can negatively affect respiratory function, whereas IBD, rheumatic disease, or multiple sclerosis does not. Moreover, in patients such as kidney transplant recipients $(n=144)$, higher mortality rate (32\%) was observed because of higher proportion of older patients and higher level of immunosuppression. ${ }^{33}$ 
Table 2 Characteristics of Patients With Myasthenia Gravis (MG) Who Died Due to Coronavirus Disease 2019 (COVID-19) From the CO-MY-COVID Registry, as of June 8, $2020(n=5)$

\begin{tabular}{|c|c|c|c|c|c|}
\hline & \multicolumn{5}{|l|}{ Patient } \\
\hline & 1 & 2 & 3 & 4 & 5 \\
\hline$M / F$ & M & $\mathrm{F}$ & $\mathrm{F}$ & M & M \\
\hline Age, y & 62 & 83 & 39 & 44 & 92 \\
\hline BMI, $\mathrm{kg} / \mathrm{m}^{2}$ & 19.9 & 25.2 & 20.0 & 26.1 & 27.1 \\
\hline Other comorbidities & Dyslip & HBP, Dyslip & Inv Vent, DM, Biermer & - & HBP \\
\hline \multicolumn{6}{|l|}{ MG } \\
\hline Antibody type & AntiAChR Ab & AntiAChR Ab & AntiAChR Ab & AntiAChR Ab & AntiAChR Ab \\
\hline Duration, y & 3 & 1 & 23 & 16 & 7 \\
\hline Thymectomy & Thymoma (2014) & - & - & - & - \\
\hline MGFA severity class at the beginning of MG & $\mathrm{Ilb}$ & IIla & $\mathrm{V}$ & $\mathrm{IVb}$ & $\mathrm{IVb}$ \\
\hline MGFA severity class at beginning of COVID-19 & $\mathrm{Ilb}$ & IIla & V & $\mathrm{IVb}$ & II \\
\hline MG treatment at the beginning of COVID-19 & Pyr 180 mg/d & $\begin{array}{l}\text { Abe } 100 \mathrm{mg} / \mathrm{d} \\
\text { Pred } 70 \mathrm{mg} / \mathrm{d}\end{array}$ & $\begin{array}{l}\text { Abe } 40 \mathrm{mg} / \mathrm{d} \\
\text { Pred } 15 \mathrm{mg} / \mathrm{d} \\
\text { Tacro } 3 \mathrm{mg} / \mathrm{d}\end{array}$ & $\begin{array}{l}\text { Pyr } 60 \mathrm{mg} / \mathrm{d} \\
\text { AZA } 100 \mathrm{mg} / \mathrm{d}\end{array}$ & $\begin{array}{l}\text { Pyr } 180 \mathrm{mg} / \mathrm{d} \\
\text { MFM 2g/d }\end{array}$ \\
\hline Rituximab in the last 6 months & - & - & - & - & - \\
\hline PLEX or IVIg in the last 6 months & - & - & - & - & - \\
\hline \multicolumn{6}{|l|}{ COVID-19 } \\
\hline Diagnoses & Probable & Definite & Definite & Definite & Definite \\
\hline PCR & - & + & + & + & + \\
\hline Chest CT scan & + & + & ND & + & + \\
\hline \multicolumn{6}{|l|}{ Affected organs } \\
\hline Upper airways & + & + & - & - & - \\
\hline Lower airways & + & + & + & + & + \\
\hline Smell/taste loss & - & - & - & - & - \\
\hline CNS & + & - & - & - & - \\
\hline Peripheral nervous system & - & - & - & - & - \\
\hline Liver & + & - & - & - & - \\
\hline Heart & - & - & + & + & - \\
\hline Renal Failure & - & - & + & + & - \\
\hline Thromboembolic disease & - & - & - & - & - \\
\hline Skin & - & - & - & - & - \\
\hline Causes of death & $\begin{array}{l}\text { ARDS } \\
\text { several bacterial infections }\end{array}$ & ARDS & $\begin{array}{l}\text { ARDS } \\
\text { Multi-organ failure }\end{array}$ & $\begin{array}{l}\text { ARDS } \\
\text { Multi-organ failure }\end{array}$ & ARDS \\
\hline COVID-19 total duration, $d$ & 25 & 7 & 9 & 28 & 21 \\
\hline Total duration of hospital stay, d & 18 & 7 & 6 & 20 & 17 \\
\hline Total duration of ICU stay, d & 18 & 7 & 6 & 20 & 0 \\
\hline MG treatment during COVID-19 & Not modified & Not modified & Not modified & Stop AZA & Not modified \\
\hline COVID-19 treatment & Pred & Tocilizumab & $\begin{array}{l}\text { HCQ } \\
\text { Ritonavir } \\
\text { Darunavir }\end{array}$ & $\begin{array}{l}\mathrm{HCQ} \\
\text { Azi }\end{array}$ & - \\
\hline
\end{tabular}

Abbreviations: Abe = ambenonium; anti-AChR Ab = anti-acetylcholine receptor antibody; ARDS = acute respiratory distress syndrome; Azi = azithromycin = $\mathrm{AZA}=$ azathioprine; $\mathrm{DM}=$ diabetes mellitus; Dyslip = dyslipidemia; HCQ = hydroxychloroquine; IVIg = IV immunoglobulin; Inv Vent = invasive ventilation; HBP = high blood pressure; MGFA = Myasthenia Gravis Foundation of America; MFM = mycophenolate mofetil; ND = not done; PLEX = plasmapheresis; Pred = prednisone; Pyr = pyridostigmin; Tacro = tacrolimus. 
Table 3 Risk Factors for Severe Coronavirus Disease 2019 (COVID-19): Univariate Ordinal Analysis and Multivariate Ordinal Regression Model Based on COVID-19 Severity (Home-Managed vs Intermediate vs Severe) Among Patients With Myasthenia Gravis (MG) $(n=34)$

\begin{tabular}{|c|c|c|c|}
\hline & \multicolumn{2}{|c|}{ Univariate ordinal analysis $(n=34)$} & \multirow{2}{*}{$\begin{array}{l}\text { Multivariate ordinal } \\
\text { regression model } \\
(\mathrm{n}=34), \text { OR }(95 \% \mathrm{Cl})\end{array}$} \\
\hline & Coefficient & $p$ Value & \\
\hline \multicolumn{4}{|l|}{ Risk factors of severe COVID-19 } \\
\hline Age & 0.02 & 0.27 & - \\
\hline Age $>65 y$ & 0.37 & 0.557 & - \\
\hline Male $($ reference $=$ female) & -0.11 & 0.865 & - \\
\hline $\mathrm{BMI}>30 \mathrm{~kg} / \mathrm{m}^{2}$ & -0.53 & 0.479 & - \\
\hline Total number of comorbidities & 0.22 & 0.274 & - \\
\hline$\geq 1$ Comorbidity & -0.05 & 0.938 & - \\
\hline \multicolumn{4}{|l|}{ MG history } \\
\hline MG duration & 0.01 & 0.742 & - \\
\hline MG duration $>2$ years & 0.8 & 0.281 & - \\
\hline High $^{\mathrm{b}}$ maximum MGFA class (reference: low + moderate) & 0.19 & 0.773 & - \\
\hline \multicolumn{4}{|l|}{$\begin{array}{l}\text { MG treatment at the beginning of COVID-19 } \\
\text { (reference = neither corticosteroids nor } \\
\text { immunosuppressants) }\end{array}$} \\
\hline Corticosteroids (without immunosuppressants) & 2.56 & 0.067 & $9.7(0.4-154.4)$ \\
\hline Immunosuppressants (without corticosteroids) & 2.56 & 0.038 & $7.2(0.6-89.7)$ \\
\hline Immunosuppressants + corticosteroids & 2.56 & 0.035 & $3.1(0.2-43.8)$ \\
\hline \multicolumn{4}{|l|}{ Corticosteroids dose (reference prednisone $\leq 20 \mathrm{mg} / \mathrm{d}$ ) } \\
\hline Prednisone $>20 \mathrm{mg} / \mathrm{d}$ & 1.84 & 0.122 & - \\
\hline \multicolumn{4}{|l|}{$\begin{array}{l}\text { MGFA class at the beginning of COVID-19 } \\
\text { (reference = low MGFA) }\end{array}$} \\
\hline Medium MGFA & 1.7 & 0.064 & $3.7(0.5-28.8)$ \\
\hline High MGFA & 4.81 & 0.0008 & $102.6(4.4-2,371.9)$ \\
\hline
\end{tabular}

Abbreviations: $\mathrm{BMI}=$ body mass index; $\mathrm{Cl}$ = confidence interval; MG-ADL = Myasthenia Gravis Activities of Daily Living; MGFA = Myasthenia Gravis Foundation of America; OR = odds ratio.

\section{Strengths and Limitations}

To our knowledge, this is the first large case series with detailed data on patients with MG with COVID-19. Eligible patients were included irrespective of where they were managed; thus, we could obtain information about milder forms of COVID-19 that have not been reported until now. Importantly, this diversity in COVID-19 severity allowed us to evaluate risk factors for severe COVID-19 in patients with MG. Lastly, this is a nationwide, multicenter study, which minimizes bias due to differences in the management of patients and due to regional variations in the prevalence rate of COVID-19.

Our study has several limitations. First, despite the large number of patients with MG recorded in the French national database for rare disorders, the total number of patients in this study remained low. The incidence rate of symptomatic COVID-19 among patients with MG is not known, but we can hypothesize that it is at least $0.96 \%(34 / 3,558)$. This result is similar to the incidence rate observed among patients with rheumatic disease $(0.62 \%)$ and in the general population $(0.66 \%)$ in Northern Italy. ${ }^{34}$ Second, although $40 \%$ of the infected patients were asymptomatic, ${ }^{35}$ only symptomatic patients were included in this study; thus, we excluded patients with MG who were asymptomatic and the consequences of asymptomatic COVID19 in patients with MG remain unknown. Third, it is possible that patients with very mild COVID-19 were less likely to be included in our cohort than those who were hospitalized, despite extensive advertising about this cohort through patient associations and contact cells of the referral centers.

Even though COVID-19 and MG represent risk factors for respiratory failure, most patients with MG infected with 
Table 4 Risk Factors for Worsening of Myasthenia Gravis (MG): Univariate Logistic Analysis Categorized Based on the Evolution of MG Among Patients $(n=34)$

\begin{tabular}{|c|c|c|}
\hline & Coefficients & $\begin{array}{l}p \\
\text { Value }\end{array}$ \\
\hline \multicolumn{3}{|l|}{ Risk factors of severe COVID-19 } \\
\hline Age $>65 y$ & 0.06 & 0.94 \\
\hline Male (reference: female) & 0.63 & 0.42 \\
\hline $\mathrm{BMI}>30, \mathrm{~kg} / \mathrm{m}^{2}$ & -0.1 & 0.91 \\
\hline Total number of comorbidities & -0.18 & 0.82 \\
\hline \multicolumn{3}{|l|}{$\begin{array}{l}\text { MG treatment at the beginning of COVID-19 } \\
\text { (reference: neither corticosteroids nor } \\
\text { immunosuppressants) }\end{array}$} \\
\hline $\begin{array}{l}\text { Corticosteroids (without } \\
\text { immunosuppressants) }\end{array}$ & 1.95 & 0.18 \\
\hline $\begin{array}{l}\text { Immunosuppressants (without } \\
\text { corticosteroids) }\end{array}$ & 1.39 & 0.26 \\
\hline $\begin{array}{l}\text { Corticosteroids and } \\
\text { immunosuppressants }\end{array}$ & 0.44 & 0.74 \\
\hline $\begin{array}{l}\text { High }^{\text {b }} \text { maximum MGFA class in MG history } \\
\text { (reference: low + moderate) }\end{array}$ & -0.7985 & 0.312 \\
\hline \multicolumn{3}{|l|}{$\begin{array}{l}\text { MGFA score at the beginning of } \\
\text { COVID-19 (reference: low) }\end{array}$} \\
\hline Medium $^{a}$ & 17.79 & 0.99 \\
\hline High $^{b}$ & 18.57 & 0.99 \\
\hline $\begin{array}{l}\text { MG-ADL score at the beginning of } \\
\text { COVID-19 }\end{array}$ & 0.13 & 0.26 \\
\hline
\end{tabular}

COVID-19 severity (reference: home-

managed)

\begin{tabular}{lcc}
\hline Intermediate & 18.18 & 1 \\
\hline Severe & 20.82 & 0.99
\end{tabular}

Abbreviations: $\mathrm{BMI}=$ body mass index; COVID-19 = coronavirus disease 2019; MG-ADL = Myasthenia Gravis Activities of Daily Living; MGFA = Myasthenia Gravis Foundation of America.

${ }^{a}$ Medium MGFA = score II, Ila, Ilb, III, IIla, or IIlb.

${ }^{\mathrm{b}}$ High MGFA = score IV, IVa, IVb, or V.

SARS-CoV-2 recovered, indicating good prognosis. Immunosuppressants and corticosteroids are not independent risk factors of severe COVID-19 in MG, but we observed higher risk of severe COVID-19 in patients with high MGFA. These results will help to establish evidence-based guidelines for the management of patients with MG during the COVID-19 pandemic outbreak.

\section{Acknowledgment}

The authors thank the patients for their participation in the CO-MY-COVID registry and Annie Archer, Vincent Pelvillain, Jean Villette (members of the group of interest on myasthenia from AFM-Téléthon), and Pierre Boulanger (president of the Association des Myasthéniques Isolés et Solidaires) for advertising for the CO-MY-COVID registry.

\section{Study Funding}

No targeted funding reported.

\section{Disclosure}

The authors declare no conflict of interest. Go to Neurology. org/ $\mathrm{N}$ for full disclosures.

\section{Publication History}

Received by Neurology August 24, 2020. Accepted in final form January 22, 2021.

Appendix Authors

\begin{tabular}{|c|c|c|}
\hline Author & Location & Contribution \\
\hline $\begin{array}{l}\text { Guilhem } \\
\text { Solé, MD }\end{array}$ & $\begin{array}{l}\text { Referral Center for } \\
\text { Neuromuscular Diseases } \\
\text { 'AOC,' Nerve-Muscle Unit, } \\
\text { University Hospitals of } \\
\text { Bordeaux (Pellegrin } \\
\text { Hospital), University of } \\
\text { Bordeaux, France }\end{array}$ & $\begin{array}{l}\text { Study concept and design; } \\
\text { acquisition and } \\
\text { interpretation of data; } \\
\text { drafting of the manuscript; } \\
\text { had full access to all of the } \\
\text { data in the study and takes } \\
\text { responsibility for the } \\
\text { integrity of the data and } \\
\text { the accuracy of the data } \\
\text { analysis }\end{array}$ \\
\hline
\end{tabular}

\begin{tabular}{|c|c|c|}
\hline $\begin{array}{l}\text { Stéphane } \\
\text { Mathis, MD, } \\
\text { PhD }\end{array}$ & $\begin{array}{l}\text { Referral Center for } \\
\text { Neuromuscular Diseases } \\
\text { 'AOC,' Nerve-Muscle Unit, } \\
\text { University Hospitals of } \\
\text { Bordeaux (Pellegrin } \\
\text { Hospital), University of } \\
\text { Bordeaux; ALS Center, } \\
\text { Nerve-Muscle Unit, } \\
\text { University Hospitals of } \\
\text { Bordeaux (Pellegrin } \\
\text { Hospital), University of } \\
\text { Bordeaux, France }\end{array}$ & $\begin{array}{l}\text { Study concept and design; } \\
\text { acquisition and } \\
\text { interpretation of data; } \\
\text { drafting of the manuscript }\end{array}$ \\
\hline $\begin{array}{l}\text { Diane } \\
\text { Friedman, } \\
\text { MD }\end{array}$ & $\begin{array}{l}\text { Department of Intensive } \\
\text { Care, Raymond Poincare } \\
\text { University Hospital, } \\
\text { Garches, France }\end{array}$ & $\begin{array}{l}\text { Acquisition and } \\
\text { interpretation of data }\end{array}$ \\
\hline $\begin{array}{l}\text { Emmanuelle } \\
\text { Salort- } \\
\text { Campana, } \\
\text { MD }\end{array}$ & $\begin{array}{l}\text { Referral Center for } \\
\text { Neuromuscular Diseases } \\
\text { and ALS, Timone } \\
\text { University Hospital, Aix- } \\
\text { Marseille University, } \\
\text { Marseille, France }\end{array}$ & $\begin{array}{l}\text { Acquisition and } \\
\text { interpretation of data; } \\
\text { critical revision of the } \\
\text { manuscript }\end{array}$ \\
\hline $\begin{array}{l}\text { Céline Tard, } \\
\text { MD }\end{array}$ & $\begin{array}{l}\text { Referral Center for } \\
\text { Neuromuscular Diseases, } \\
\text { Department of Neurology, } \\
\text { University Hospitals of } \\
\text { Lille, France }\end{array}$ & $\begin{array}{l}\text { Acquisition and } \\
\text { interpretation of data }\end{array}$ \\
\hline $\begin{array}{l}\text { Françoise } \\
\text { Bouhour, MD }\end{array}$ & $\begin{array}{l}\text { Referral Center for } \\
\text { Neuromuscular Diseases, } \\
\text { ENMG unit, University } \\
\text { Hospitals of Lyon } \\
\text { (Neurologic Hospital } \\
\text { Pierre Wertheimer), Lyon, } \\
\text { France }\end{array}$ & $\begin{array}{l}\text { Acquisition and } \\
\text { interpretation of data }\end{array}$ \\
\hline $\begin{array}{l}\text { Armelle } \\
\text { Magot, MD }\end{array}$ & $\begin{array}{l}\text { Referral Center for } \\
\text { Neuromuscular Diseases, } \\
\text { University Hospitals of } \\
\text { Nantes, France }\end{array}$ & $\begin{array}{l}\text { Acquisition and } \\
\text { interpretation of data; } \\
\text { critical revision of the } \\
\text { manuscript }\end{array}$ \\
\hline $\begin{array}{l}\text { Djillali } \\
\text { Annane, MD, } \\
\text { PhD }\end{array}$ & $\begin{array}{l}\text { Department of Intensive } \\
\text { Care, Raymond Poincare } \\
\text { University Hospital, } \\
\text { Garches, France }\end{array}$ & $\begin{array}{l}\text { Acquisition and } \\
\text { interpretation of data }\end{array}$ \\
\hline
\end{tabular}


Appendix (continued)

\begin{tabular}{lll}
\hline Author & Location & Contribution \\
\hline $\begin{array}{l}\text { Bernard } \\
\text { Clair, MD }\end{array}$ & $\begin{array}{l}\text { Department of Intensive } \\
\text { Care, Raymond Poincare } \\
\text { University Hospital, } \\
\text { Garches, France }\end{array}$ & $\begin{array}{l}\text { Acquisition and } \\
\text { interpretation of data }\end{array}$ \\
\hline Gwendal Le & Referral Center for & \\
Masson, MD, & Neuromuscular Diseases & Acquition and \\
PhD & 'AOC,' Nerve-Muscle Unit, & supervision \\
& Nerve-Muscle Unit, & \\
& University Hospitals of & \\
& Bordeaux (Pellegrin \\
& Hospital), University of & \\
& Bordeaux; ALS Center, & \\
& Nerve-Muscle Unit, & \\
& University Hospitals of \\
& Bordeaux (Pellegrin \\
& Hospital), University of \\
& Bordeaux, France &
\end{tabular}

\begin{tabular}{lll}
\hline $\begin{array}{l}\text { Antoine } \\
\text { Soulages, MD }\end{array}$ & $\begin{array}{l}\text { Referral Center for } \\
\text { Neuromuscular Diseases } \\
\text { 'AOC,' Nerve-Muscle Unit, } \\
\text { Nerve-Muscle Unit, }\end{array}$ & $\begin{array}{l}\text { Acquisition and } \\
\text { interpretation of data; } \\
\text { administrative, technical, } \\
\text { or material support }\end{array}$ \\
& Bniversity Hospitals of & \\
& Hospital), University of \\
& Bordeaux; ALS Center, \\
& Nerve-Muscle Unit, \\
& University Hospitals of \\
& Bordeaux (Pellegrin \\
& Hospital), University of \\
& Bordeaux, France
\end{tabular}

Fanny Duval Referral Center for

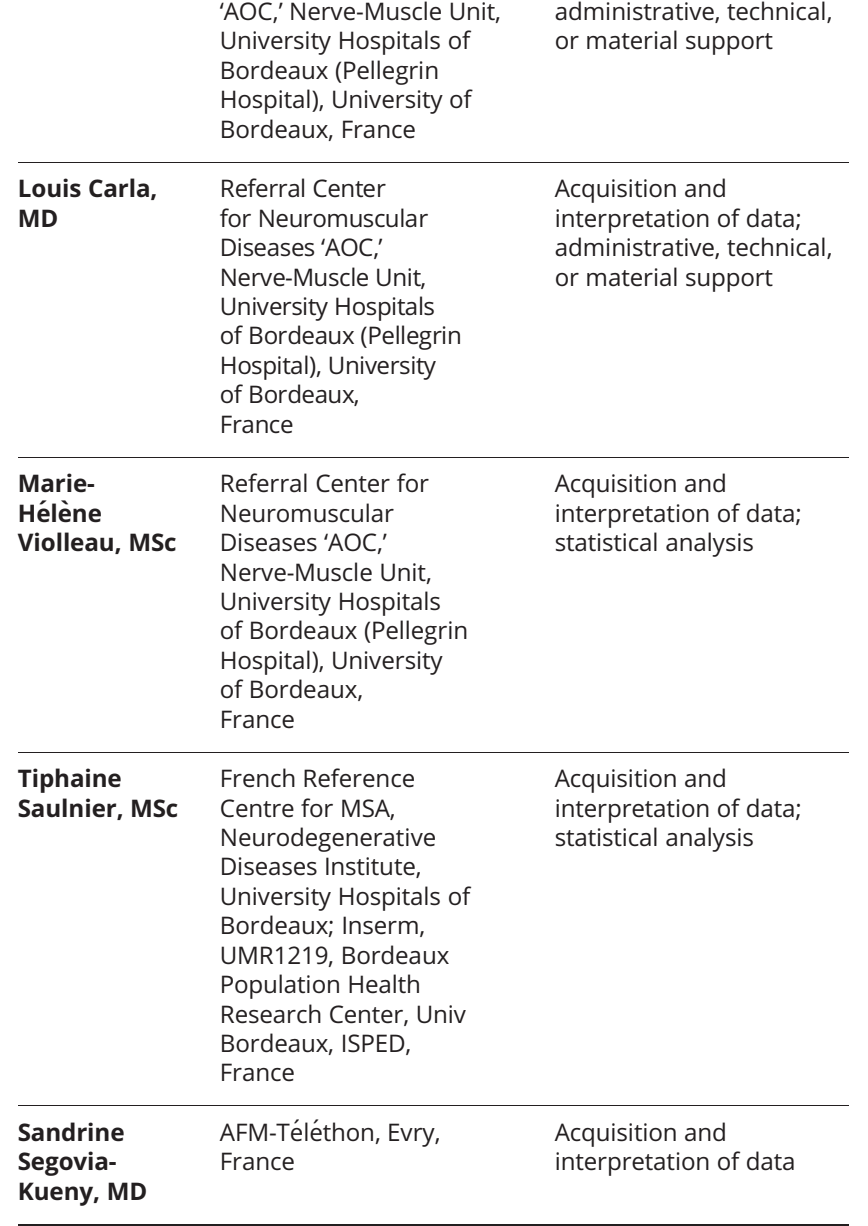

Appendix (continued)

\begin{tabular}{|c|c|c|}
\hline Author & Location & Contribution \\
\hline Léa Kern, MD & $\begin{array}{l}\text { Department of Neurology, } \\
\text { General Hospital of Le } \\
\text { Mans, France }\end{array}$ & $\begin{array}{l}\text { Acquisition and } \\
\text { interpretation of data }\end{array}$ \\
\hline $\begin{array}{l}\text { Jean- } \\
\text { Christophe } \\
\text { Antoine, MD }\end{array}$ & $\begin{array}{l}\text { Department of Neurology, } \\
\text { University Hospital of } \\
\text { Saint-Etienne, France }\end{array}$ & $\begin{array}{l}\text { Acquisition and } \\
\text { interpretation of data }\end{array}$ \\
\hline $\begin{array}{l}\text { Guillemette } \\
\text { Beaudonnet, } \\
\text { MD }\end{array}$ & $\begin{array}{l}\text { Clinical Neurophysiology } \\
\text { and Epileptology } \\
\text { Department, University } \\
\text { Hospital of Bicêtre, Le } \\
\text { Kremlin-Bicêtre, } \\
\text { France }\end{array}$ & $\begin{array}{l}\text { Acquisition and } \\
\text { interpretation of data }\end{array}$ \\
\hline $\begin{array}{l}\text { Frédérique } \\
\text { Audic, MD }\end{array}$ & $\begin{array}{l}\text { Referral Center for } \\
\text { Neuromuscular Diseases, } \\
\text { Neuropediatric Unit, } \\
\text { Timone University } \\
\text { Hospital, Marseille, France }\end{array}$ & $\begin{array}{l}\text { Acquisition and } \\
\text { interpretation of data }\end{array}$ \\
\hline $\begin{array}{l}\text { Laurent } \\
\text { Kremer, MD, } \\
\text { PhD }\end{array}$ & $\begin{array}{l}\text { Referral Center for } \\
\text { Neuromuscular } \\
\text { Diseases 'Nord-Est-lle de } \\
\text { France,' Neurology } \\
\text { Department, University } \\
\text { Hospitals of Strasbourg, } \\
\text { France }\end{array}$ & $\begin{array}{l}\text { Acquisition and } \\
\text { interpretation of data }\end{array}$ \\
\hline $\begin{array}{l}\text { Jean-Baptiste } \\
\text { Chanson, } \\
\text { MD, PhD }\end{array}$ & $\begin{array}{l}\text { Referral Center for } \\
\text { Neuromuscular } \\
\text { Diseases 'Nord-Est-Ile } \\
\text { de France,' Neurology } \\
\text { Department, University } \\
\text { Hospitals of Strasbourg, } \\
\text { France }\end{array}$ & $\begin{array}{l}\text { Acquisition and } \\
\text { interpretation of data }\end{array}$ \\
\hline $\begin{array}{l}\text { Aleksandra } \\
\text { Nadaj- } \\
\text { Pakleza, MD, } \\
\text { PhD }\end{array}$ & $\begin{array}{l}\text { Referral Center for } \\
\text { Neuromuscular Diseases } \\
\text { 'Nord-Est-lle de France,' } \\
\text { Neurology Department, } \\
\text { University Hospitals of } \\
\text { Strasbourg, France }\end{array}$ & $\begin{array}{l}\text { Acquisition and } \\
\text { interpretation of data }\end{array}$ \\
\hline $\begin{array}{l}\text { Tanya } \\
\text { Stojkovic, } \\
\text { MD }\end{array}$ & $\begin{array}{l}\text { Referral Center for } \\
\text { Neuromuscular Diseases } \\
\text { 'Nord-Est-lle de France,' } \\
\text { APHP (Pitié-Salpêtrière } \\
\text { Hospital), Sorbonne } \\
\text { University, Paris, } \\
\text { France }\end{array}$ & $\begin{array}{l}\text { Acquisition and } \\
\text { interpretation of data; } \\
\text { critical revision of the } \\
\text { manuscript }\end{array}$ \\
\hline $\begin{array}{l}\text { Pascal } \\
\text { Cintas, MD }\end{array}$ & $\begin{array}{l}\text { Referral Center for } \\
\text { Neuromuscular Diseases, } \\
\text { Department of Neurology, } \\
\text { University Hospitals of } \\
\text { Toulouse (Purpan } \\
\text { Hospital), France }\end{array}$ & $\begin{array}{l}\text { Acquisition and } \\
\text { interpretation of data }\end{array}$ \\
\hline $\begin{array}{l}\text { Marco } \\
\text { Spinazzi, MD, } \\
\text { PhD }\end{array}$ & $\begin{array}{l}\text { Referral Center for } \\
\text { Neuromuscular Diseases, } \\
\text { Department of Neurology, } \\
\text { University Hospital of } \\
\text { Angers, France }\end{array}$ & $\begin{array}{l}\text { Acquisition and } \\
\text { interpretation of data; } \\
\text { critical revision of the } \\
\text { manuscript }\end{array}$ \\
\hline $\begin{array}{l}\text { Alexandra } \\
\text { Foubert- } \\
\text { Samier, MD, } \\
\text { PhD }\end{array}$ & $\begin{array}{l}\text { French Reference Centre } \\
\text { for MSA, } \\
\text { Neurodegenerative } \\
\text { Diseases Institute, } \\
\text { University Hospitals of } \\
\text { Bordeaux; Inserm, } \\
\text { UMR1219, Bordeaux } \\
\text { Population Health } \\
\text { Research Center, Univ } \\
\text { Bordeaux, ISPED, France }\end{array}$ & $\begin{array}{l}\text { Acquisition and } \\
\text { interpretation of data; } \\
\text { statistical analysis; critical } \\
\text { revision of the manuscript }\end{array}$ \\
\hline
\end{tabular}

Continued

-

MD Neuromuscular Diseases

'AOC,' Nerve-Muscle Unit,

University Hospitals of

Bordeaux (Pellegrin

Hospital), University of

Bordeaux, France

Acquisition and

interpretation of data; administrative, technical, or material support 
Appendix (continued)

\begin{tabular}{|c|c|c|}
\hline Author & Location & Contribution \\
\hline $\begin{array}{l}\text { Shahram } \\
\text { Attarian, MD, } \\
\text { PhD }\end{array}$ & $\begin{array}{l}\text { Referral Center for } \\
\text { Neuromuscular Diseases } \\
\text { and ALS, Timone } \\
\text { University Hospital, Aix- } \\
\text { Marseille University, } \\
\text { Marseille, France }\end{array}$ & $\begin{array}{l}\text { Acquisition and } \\
\text { interpretation of data; } \\
\text { study concept and design; } \\
\text { critical revision of the } \\
\text { manuscript; supervision }\end{array}$ \\
\hline
\end{tabular}

\section{References}

1. Wu Z, McGoogan JM. Characteristics of and important lessons from the coronavirus disease 2019 (COVID-19) outbreak in China: summary of a report of 72314 cases from the Chinese Center for Disease Control and Prevention. JAMA 2020;323:1239-1242.

2. Shi Y, Wang G, Cai XP, et al. An overview of COVID-19. J Zhejiang Univ Sci B 2020; 21:343-360.

3. World Health Organization. Clinical Management of Severe Acute Respiratory Infection when Novel Coronavirus ( $\mathrm{nCoV}$ ) Infection is Suspected: Interim Guidance, 2020. Geneva: World Health Organization; 2020.

4. Sharma A, Tiwari S, Deb MK, Marty JL. Severe acute respiratory syndrome coronavirus-2 (SARS-CoV-2): a global pandemic and treatment strategies. Int J Antimicrob Agents 2020;56:106054

5. Guidon AC, Amato AA. COVID-19 and neuromuscular disorders. Neurology 2020; 94:959-969.

6. Solé G, Salort-Campana E, Peréon Y, et al. Guidance for the care of neuromuscular patients during the COVID-19 pandemic outbreak from the French Rare Health Care for Neuromuscular Diseases Network. Rev Neurol 2020;176:507-515.

7. Jacob S, Muppidi S, Guidon A, et al. Guidance for the management of myasthenia gravis (MG) and Lambert-Eaton Myasthenic Syndrome (LEMS) during the COVID-19 pandemic. J Neurol Sci 2020;412:116803.

8. Anand P, Slama MCC, Kaku M, et al. COVID-19 in patients with myasthenia gravis. Muscle Nerve 2020;62:254-258.

9. Singh S, Govindarajan R. COVID-19 and generalized myasthenia gravis exacerbation: a case report. Clin Neurol Neurosurg 2020;196:106045.

10. Kushlaf H. COVID-19 in muscle-specific kinase myasthenia gravis: a case report. Muscle Nerve 2020;62:E65-E66.

11. Hubers A, Lascano AM, Lalive PH. Management of patients with generalised myasthenia gravis and COVID-19: four case reports. J Neurol Neurosurg Psychiatry 2020; 91:1124-1125.

12. Muppidi S, Guptill JT, Jacob S, et al. COVID-19-associated risks and effects in myasthenia gravis (CARE-MG). Lancet Neurol 2020;19:970-971.

13. Wollina U, Karadag AS, Rowland-Payne C, Chiriac A, Lotti T. Cutaneous signs in COVID-19 patients: a review. Dermatol Ther 2020:e13549.

14. Huang P, Liu T, Huang L, et al. Use of chest CT in combination with negative RTPCR assay for the 2019 novel coronavirus but high clinical suspicion. Radiology 2020; 295:22-23.

15. Jaretzki A III, Barohn RJ, Ernstoff RM, et al. Myasthenia gravis: recommendations for clinical research standards. Task Force of the Medical Scientific Advisory Board of the Myasthenia Gravis Foundation of America. Neurology 2000;55:16-23.
16. Gilhus NE. Myasthenia gravis. N Engl J Med 2016;375:2570-2581.

17. Thomas CE, Mayer SA, Gungor Y, et al. Myasthenic crisis: clinical features, mortality, complications, and risk factors for prolonged intubation. Neurology 1997;48: $1253-1260$.

18. Gilhus NE, Romi F, Hong Y, Skeie GO. Myasthenia gravis and infectious disease. J Neurol 2018;265:1251-1258.

19. Ramos-Fransi A, Rojas-Garcia R, Segovia S, et al. Myasthenia gravis: descriptive analysis of life-threatening events in a recent nationwide registry. Eur J Neurol 2015; 22:1056-1061.

20. Jordan RE, Adab P, Cheng KK. Covid-19: risk factors for severe disease and death. BMJ 2020;368:m1198.

21. Carr AS, Cardwell CR, McCarron PO, McConville J. A systematic review of population based epidemiological studies in myasthenia gravis. BMC Neurol 2010;10:46.

22. Santé Publique France. COVID-19: Point épidémiologique hebdomadaire du 0 octobre 2020. Santé Publique France; 2020.

23. Horby P, Lim WS, Emberson JR, et al. Dexamethasone in hospitalized patients with Covid-19: preliminary report. N Engl J Med 2020:NEJMoa2021436.

24. Sterne JAC, Murthy S, Diaz JV, et al. Association between administration of systemic corticosteroids and mortality among critically ill patients with COVID-19: a metaanalysis. JAMA 2020;324:1330-1341.

25. Angus DC, Derde L, Al-Beidh F, et al. Effect of hydrocortisone on mortality and organ support in patients with severe COVID-19: the REMAP-CAP COVID-19 corticosteroid domain randomized clinical trial. JAMA 2020;324:1317-1329.

26. Gianfrancesco M, Hyrich KL, Al-Adely S, et al. Characteristics associated with hospitalisation for COVID-19 in people with rheumatic disease: data from the COVID19 Global Rheumatology Alliance Physician-Reported Registry. Ann Rheum Dis 2020;79:859-866.

27. Cappello M, Busacca A, Guida L. The course of COVID-19 in inflammatory bowel disease: protective role of TNF antagonists response to corticosteroids, but not TNF antagonists, are associated with adverse COVID-19 outcomes in patients with inflammatory bowel diseases: results from an international registry. Gastroenterology Epub $2020 \mathrm{Jul} 6$.

28. Louapre C, Collongues N, Stankoff B, et al. Clinical characteristics and outcomes in patients with Coronavirus disease 2019 and multiple sclerosis. JAMA Neurol 2020;77: 1079-1088.

29. Anand P, Slama MCC, Kaku M, et al. Comment on COVID-19 in patients with myasthenia gravis: author response. Muscle Nerve 2020;62:E87-E88.

30. Sharifian-Dorche M, Huot P, Osherov M, et al. Neurological complications of coronavirus infection; a comparative review and lessons learned during the COVID19 pandemic. J Neurol Sci 2020;417:117085.

31. Seok HY, Shin HY, Kim JK, et al. The impacts of influenza infection and vaccination on exacerbation of myasthenia gravis. J Clin Neurol 2017;13:325-330.

32. D'Silva KM, Serling-Boyd N, Wallwork R, et al. Clinical characteristics and outcomes of patients with coronavirus disease 2019 (COVID-19) and rheumatic disease: a comparative cohort study from a US 'hot spot.' Ann Rheum Dis 2020;79:1156-1162.

33. Cravedi P, Suraj SM, Azzi Y, et al. COVID-19 and kidney transplantation: results from the TANGO International Transplant Consortium. Am J Transpl 2020;20: 3140-3148.

34. Favalli EG, Monti S, Ingegnoli F, Balduzzi S, Caporali R, Montecucco C. Incidence of COVID-19 in patients with rheumatic diseases treated with targeted immunosuppressive drugs: what can we learn from observational data? Arthritis Rheumatol 2020, 72:1600-1606.

35. Oran DP, Topol EJ. Prevalence of asymptomatic SARS-CoV-2 infection: a narrative review. Ann Intern Med 2020;173:362-367. 


\section{Neurology}

Impact of Coronavirus Disease 2019 in a French Cohort of Myasthenia Gravis Guilhem Solé, Stéphane Mathis, Diane Friedman, et al.

Neurology 2021;96;e2109-e2120 Published Online before print February 10, 2021

DOI 10.1212/WNL.0000000000011669

This information is current as of February 10, 2021

\section{Updated Information \&} Services

References

Subspecialty Collections

Permissions \& Licensing

Reprints including high resolution figures, can be found at: http://n.neurology.org/content/96/16/e2109.full

This article cites 30 articles, 7 of which you can access for free at: http://n.neurology.org/content/96/16/e2109.full\#ref-list-1

This article, along with others on similar topics, appears in the following collection(s):

\section{COVID-19}

http://n.neurology.org/cgi/collection/covid_19

Myasthenia

http://n.neurology.org/cgi/collection/myasthenia

Information about reproducing this article in parts (figures,tables) or in its entirety can be found online at:

http://www.neurology.org/about/about_the_journal\#permissions

Information about ordering reprints can be found online:

http://n.neurology.org/subscribers/advertise

Neurology ${ }^{\circledR}$ is the official journal of the American Academy of Neurology. Published continuously since 1951, it is now a weekly with 48 issues per year. Copyright @ 2021 American Academy of Neurology. All rights reserved. Print ISSN: 0028-3878. Online ISSN: 1526-632X.

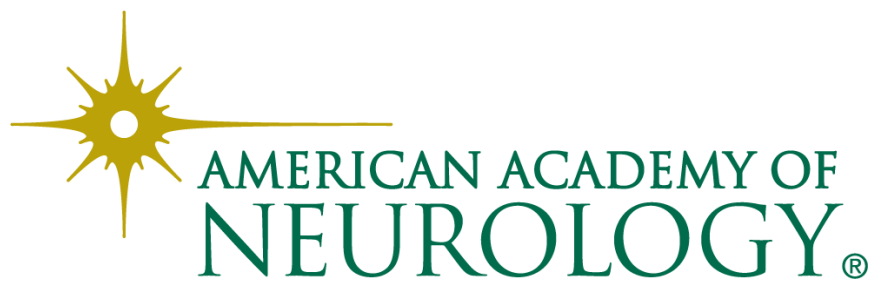

